\title{
The Last Trouveur of France: Genesis of Francis Poulenc's Oeuvre
}

\author{
Ganna Rizaieva ${ }^{1, *}$ \\ ${ }^{1}$ World Music History Department, P.I. Tchaikovsky National Music Academy of Ukraine, Kyiv, Ukraine \\ *Corresponding author. anriza777@gmail.com
}

\begin{abstract}
This article reviews one of the defining aspects of genesis of the oeuvre of the famous French composer of XX century - Francis Poulenc. It outlines dominant features of the artist's personality - universality of thinking, paradoxicality, organic coexistence of sacred and secular, feminocentrism, lyricism - and traces their direct connections with cultural codes of the High and Late Middle Ages, in particular with the art of troubadours and trouveurs. The article points out the unique integrity of Poulenc's multilevel artistic world through the metaphor of XIII century polytextual motet. It proves that the awareness of the origins of Poulenc's style provides deep understanding of the psychology of his artistic method and allows reinterpretation of the composer's role and place in the modern cultural space.
\end{abstract}

\section{Keywords: F. Poulenc, artistic world, genesis, troubadours, trouveurs, Black Virgin of Rocamadour, opera}

\section{INTRODUCTION}

Eclectic and full of internal paradoxical contradictions, the artistic world of Francis Poulenc attracts researchers trying to find the key to the mystery of his artistic genius. Poulenc's aesthetic, style and imaginal omnivorousness, his devotedness to the traditional forms and adherence to tonal system, though reconsidered by the artist in his works, for a long time, were the stumbling point for the critics and proponents of New Music: post-war avant-gardists headed by Pierre Boulez "labeled" Poulenc's music as "frivolous pre-war relic" [1]. In spite of lifetime worldwide recognition of Poulenc's opera and vocal music, at the end of the XX century, his choral and church pieces were more known in the USA and Great Britain than in his native country. 1994 publication of the ultimate collection of Poulenc's letters under the editorship of $\mathrm{M}$. Chimènez [2] has become a kind of "renaissance" for re-interpretation of the artist's personality and, as a result, all heritage of the French composer. Over the last 20 years, there were many researches where unbiased voices of musicologists defended novel approaches to the French composer by breaking stereotypes about the so-called frivolousness of his music and his out-of-date language. The researchers most often limit themselves to stating that eclecticism, dichotomy and ambivalence are the main characteristics of Poulenc's style. However, the simple listing of elements of his style does not bring us closer to the understanding of the defining senses of his artistic paradigm and in no way nears us to the discovery of the phenomenon of the composer's oeuvre. "Genetic" codes of the unique artistic matrix of Poulenc can only be found by immersion into complex and paradoxical artistic world of the composer with regard to the whole history of European musical culture development. Poulenc's art genesis exploration is the main focus of this article showing connection of the artistic world of the XX century French composer with French medieval culture, in particular with trouveur art.

\section{POULENC'S ART EXISTENCE}

The brilliant thought of P. Valery "what is not like anything else does not exist" addresses the eternal issue of art existence directly related to existence of eternal universes of senses, images, ideas that, similar to cosmologic parallel universes, are sources or, in some way, defining matrixes for the new phenomena and formations. And a chain of 'universes' developing and appearing from them is, at its core, isomorphic and openly-infinite [3].

In the study of Poulenc's artistic world paradigm, the issue of his art existence is fundamental. All the time, he was lynched for the "detected similarity" with many composers and even accused for having "not a single original note" and that "each bar can be traced to Chopin or Mussorgsky, or Ravel, or Stravinsky or even Faure he hated" [4], noting, at the same time, that "using musical dictionary of all" [5], "each of his bars can be immediately identified as pure Poulenc." [6].

Poulenc's unique style originated from the prodigious talent to feel and absorb the world around him. This talent produced vibrant, almost feelable musical spaces - inspired and infused with impressions from stained-glass artworks and paintings as well his 
remarkable ability to copy, by means of music, intonation of the authors to whose words he set his music. For all that, through allusions, stylistic borrowings and "poet's voices", Poulenc is first of all vocalizing himself, his unique inner world and those energetic emanations penetrating through him and melting, in the process of creation, all collisions and contradictions into, as it was nicely put by the French Poulenc scholar Hervé Lacombe, "radiant fireness" [7]. Upon a closer view, in the process of ingression into Poulenc's artistic world and exploration of his extraordinary integrity, one is tempted to find and mark the space of his "primary matrix".

In the search of the "baseline universe" of Poulenc's artistic world, it is necessary to literally "trudge" through the universal stylistic omnivorousness of the $\mathrm{XX}$ century. It is obvious that the integral symbol of the epoch in which Poulenc was developing and working is communicative dialogue with multiple historical layers. In this "melting pot of history" each "chose" one's own inspirational foretype (baroque, renaissance etc.) that, in each case, was implemented in a unique way creating different systems and styles in the future.

However, Poulenc's case is exceptional. The composer was saying, time and again "My model is my instinct" [8]. Paradoxicality, spontaneity, instinctiveness, co-existence of seemingly conflicting high (religious) and low (naughty and even vulgar) characters and finally sublime inspiration with amazing symmetry and clarity of the form spontaneously evoke images either of the medieval cathedral - multilevel and directed to the heavens, or medieval manuscript with its mind-blowing incompatibility of metaphoric spheres peaceful coexistence of Scripture texts with periodical sketches of marginalia. According to medievalists, such combination of secular and sacred was not regarded as something improper or disrespectful, while in this case English medievalist Alec Harman points out to the "art of analogy" where earthly feelings and mystic miracles of this world helped to understand and partially reflect the Glory of God [9].

\section{ADORATION OF THE BLACK VIRGIN}

"To the Glory of God" - this is how Poulenc put his plea to the Blessed Virgin Mary to make him a gift of libretto to the religious text from which one of the glorious XX century works will be born - religious mystic opera Dialogues of the Carmelites (1956). Amidst the Bacchanalia of godless (M. Heidegger) and non-religious (D. Bonhoeffer) XX century, anthropologic crisis, and crazy theories of social institutes restructuring - when practically everyone from early years of divinity school knew that "God does not exist" - this sincere and naïve composers' confession of Virgin Mary protection sounds so... Poulenc-like!
37 years were needed for the spirit of his Franciscan forefathers ${ }^{1}$ to bring the mischief-maker to the medieval sanctuary of Catholicism - Rocamadour where, according to the composer himself, he had lived through mystic experience. It was there and then that his first spiritual work was born - Litany for the Black Virgin for female choir and organ.

Spiritual turning point that added deep religious overtones to the varicolored secular palette of Poulenc's artistic image had its external cause - tragic death of his friend and colleague P.-O. Ferroud in 1936. However, according to $\mathrm{H}$. Lacombe, even before this crucial moment of the composer's life, his psycho-emotional state was marked by abnormal "accumulation and retraumatization" [10] facilitated by early death of his parents and death of several close friends over a short period of time ${ }^{2}$. Ferroud's death was the final straw to Poulenc's existential anxiety that called for spiritual transformation for which he kneeled 216 steps and 14 flights of the exhausting Rocamadour path to the Chapelle Notre-Dame in order to "meet" the Black Virgin who would become his divine patroness until the end of life. "Thinking about the fragility of our human body, I was once again engaged into the life of spirit." [11]. During the last 27 years of his $\operatorname{life}^{3}$ the composer glorified the Black Virgin of Rocamadour in his works: Litany for the Black Virgin (1936) for a three-part choir of women and organ, Salve Regina (1941) for mixed choir a cappella, Salut, Dame Sainte, reine très sainte, mère de Dieu, Four Small Prayers of Saint Francis of Assisi (1948) for male choir a cappella, Stabat Mater (1950) for soprano solo, mixed choir and orchestra. These works, with various content and emotionality, dedicated to the Blessed Virgin Mary make a kind of Poulenc's musical rosarium from the most important gospel stories - the great mystery of Annunciation, bright joy of Christmas, despair of Christ's crucifixion tragedy, and consoling-exalted prayers to Virgin Mary.

Poulenc's choice of his patroness Madonna is interesting in many aspects. According to the American researcher L. C. Birnbaum, "Black Madonna is a metaphor - tribute to the times when it was believed that the earth is a female body" [12]. Black Virgin cult originated in the most ancient pagan rituals of fertility, land and birth of life. According to many scholars, this explains the black color symbolizing life-giving energy of earth and mother's womb giving new life. Secondly,

Father's side of Poulenc's family was very religious: brother of Poulenc's great grandfather, abbot Joseph Poulenc, was parish priest of Ivry-sur-Seine church, second cousin - Franciscan monk. F. Poulenc many times said that his return to "spiritual life" at the age of 37 was revival of his childhood faith cultivated by his father from the composer's early years of life.

Several years before Ferroud's death, Poulenc lost other close friend Raymonde Linossier - "black violet", "spiritual mentor" of his youth

He will die in his sleep on January 30, 1963 
this color is a direct reference to a very popular medieval occupation - spiritual alchemy the task of which was soul transformation for coalescence with the divine. The first stage of the spiritual alchemic process was called "blackening" and meant blackness of death and decay of the old erroneous convictions about oneself - the stage of conscious integration of the soul back into the physical world and body. Black Virgin reflected this absolutely necessary step by skin color as if giving life to the process of spiritual transmutation. Finally, according to the French scholar J. Huynen, medieval Fair Lady admiration originated from religious-mystic adoration of Black Madonna by Templar Knights [13].

It should be noted that Black Virgin of Rocamadour is one of the most ancient statues of the kind (XII century), while Rocamadour itself is located in Aquitaine - homeland of troubadours. It was at the court of William IX, the Duke of Aquitaine called the Troubadour, that the code of fin'amor (according to the French medievalist P. Zumthor, - love "with regard to alchemic connotation - sophisticated, "refined", purified from any admixtures, quintessential" [14]) was created and the new genre of lyric song was born lyrics of these songs were not in Latin, but in the spoken language. Later, in the works of trouveurs, adoration of the Fair Lady transformed in the unreachable spiritual cleanliness of serving the Virgin Mary. G. de Coincy (1177-1236) is one of the prominent examples of the above. He authored a book of poetic miracle plays The Miracles of Notre Dame and also first paralithurgic songs glorifying the Virgin Mary in French. De Coincy's peculiarities of Virgin Mary adoration were his liberal views at Christian dogmas and rejection of their strict morals. He poeticizes specific relations between non-Orthodox believer and Virgin Mary: "The more raffish the Virgin's suppliant, the better she likes him. (...) On the single condition that they sing her praises, usually by reciting the Ave Maria, and show due respect for the miracle of the Incarnation wrought in her, they can do no [fundamental] wrong. (...) Through her the whole gay crew of wanton, loving, weak humanity finds its way to Paradise..." [15]

Theme migration and auto-quotation is one of the defining features of Poulenc's style. Intercrossing of intonation structures of secular and sacred can be found all the time. For instance, the cycle Four Penitential Motets written in 1939 is close, by figural content, to Gmoll concert for organ, timpani and string orchestra (1938): ; intonation similarity is traceable between orchestra entrance to the Litany to the Black Virgin (1936) and choral theme of the intermission of The Breasts of Tiresias (1947) and Monastery theme from the Dialogues of the Carmelites (1956), between the themes of mono opera Human Voice (1959) and Responsory of the Holy Week (1962). For theme development of the Clarinet Sonata (1962), Poulenc uses the music material Gloria ("Domine Deus, Agnus Dei"), while thematic inventions from the First and Third Responsories, the first of the Four Small Prayers of Saint Francis of Assisi and Litany to the Black Virgin infuse the Oboe Sonata (1962).

\section{IV. "HOMO UNIVERSALIS'}

Poulenc mastered a very rare for the XX century "syncretic unity of action" that in its day was an unquestionable feature of High and Late Middle Ages professional music formation. The so-called Homo Universalis type - the first and bright representative of which was Guillaume de Machaut - was characterized by literature and musical genius, organic co-existence of secular and sacred works, ability to create works of different genres, excellence in different fields [16]. To some extent, all these qualities could also be seen in Poulenc's unique artistic personality.

Not only was he a non-mainstream composer, but also a wonderful pianist and a brilliant accompanist ${ }^{4}$. Many audio and video recordings of Poulenc's concerts with the famous French baritone P. Bernac (who was his friend of many years) and his muse - soprano singer D. Duval are available now in EMI and Ricordi digitized sound recordings and are published on YouTube. Poulenc's European and world concert tours were always a success with a public and praised by the critics.

Having a sophisticated literary talent, Poulenc himself acted as musical critic and collaborated with French and English press (Fanfare, Arts phoniques, Le Figaro etc.). But his literary talent was not limited by this. In 2011, Fayard published a book called I Write Music that Sings to Me [17] - a full collection of Poulenc's literary works - more than 120 texts (around 1000 (!) pages in total) including monography dedicated to creative work of $\mathrm{E}$. Chabrier, many articles, interviews with S. Audel and C. Rostand in which Poulenc, wittily, with a fine sense of humor and great depth at the same time, not only shares his observations on his time, cultural mainstreams of the epoch, but also, as a person with keen senses, reflects upon his inwardness and even about place and role of composer... Francis Poulenc in history! Attention to his inner world, importance of understanding of his place and role as a composer (the first lifetime monography about Poulenc was ordered by the composer himself for his friend - musical critic $\mathrm{H}$. Hell), overriding personhood of programs or associations between his works and close people [18], his extraordinary correspondence representing the real chronicle of the "forty-year period of Paris musical life, from 1920's to

\footnotetext{
We remind that his mentor was an outstanding virtuoso of the piano of the XX century Ricardo Viñes
} 
1960's" [19] where Poulenc made sincere statements about his works again brings about certain allusion to the above-mentioned Guillaume de Machaut in whose works autobiographical nature and realization of the "value of his own oeuvre and desire to comprehend it" [20] are the defining features.

Working on libretto to his operas, Poulenc demonstrates an outstanding dramaturgic talent. Though the original literary sources - Apollinaire's surrealistic drama, Bernanos' cinematographic dialogues and Cocteau's monodrama - ran very well and enjoyed great success in the theater, but they are generally regarded as hardly suitable for the opera theater. Their adaptation by Poulenc to libretto is undoubtedly a great example of this genre work. In general, work with operas revealed not only his extraordinary dramaturgic talent, but also his fantastic music-stagecraft genius. In his operas, Poulenc unfolds marginally visible world, overfilled with emotions and actions (even in mono opera!). Clear expressiveness of the word amplified by intonation nuances of vocal melody and very special and brightly prominent role of the orchestra performing different dramaturgic functions create poly-textuality, prominence and plasticity of the artistic world of Poulenc's operas. And finally, everything in his operas is "working" to demonstrate their picturesqueness and performability. "I learnt technique from the musicians, but I get the ideas from writers and artists. I have poetic mindset, I think visually, definitely, non-abstract" [21]

Syncretic mindset of the composer is traceable in the unique artistic world created by him. To the scholar with an inquiring mind, it unfolds as a fascinated dynamic picture webbed by the three main imagebearing spheres - spiritual/sacred (in a very real, religious, sense), secular resting on the wings of strikingly intimate stripping sensuality and light-headed enchantment and shamelessly coexisting with them "folk" sphere with somewhat rough and brutal sense of humor up to the obscene, i.g. Chansons gaillardes or some scenes from The Breasts of Tiresias. It should be pointed out that, according to J. Huizinga, chimeric mix of asceticism and erotic is characteristic feature of the late medieval culture, and at that time their manifestations could be extreme.

Each of the above spheres is crowned by one of the three Poulenc's operas: lyrical farce (buff opera) The Breasts of Tiresias, religious-mystic drama Dialogues of the Carmelites and lyrical-psychological mono-opera (lyrical tragedy) Human Voice, which demonstrates paradoxical integrity of Poulenc's multilevel artistic world. If it were possible to provide a universal genre definition for it, the most suitable would have been a polytextual motet - the unique artefact of fusion of religious, secular and profane texts sounding in tune the main genre of the Late Middle Ages, the genre so much loved by the trouveurs among whom are A. de la Halle, P. de la Croix, G. de Machaut. With this in view, it is striking that Poulenc was the one who practically revived the genre of motet in the $\mathrm{XX}$ century by creation of cycles of Penitential and Christmas Motets.

\section{FEMINOCENTRISM AS A DOMINANT OF POULENC'S OEUVRE}

Integrative basis of the artistic world of Poulenc's antipodal - by genre, characters and image-bearing spheres - operas is feminocentrism, in spite of the fact that quality of this "centrism" is different in each opera. Despite all the differences in the artistic reality where they are living and they are making themselves, Thérèse from The Breasts of Tiresias with her "eccentric insanities", Blanche from the Dialogues of the Carmelites tortured by fear and anguished nameless woman from the Human Voice with a phone receiver are united not only by their incredible beneficence and the first performer Denise Duval ${ }^{5}$ (in a way, she is undoubtedly a creator of these characters). All three of the women are characterized by pure Femininity manifested in lyrical episodes of the opera that are full of sensuality, and all three, no matter how trivial this sounds, are exceptionally Beautiful. According to B. de Schloezer, this Beauty is where novelty of Poulenc's music is to be found [23].

French culture of the late XIX century was characterized by a very intensive search for the new artistic paradigm where the phenomenon of beauty was regarded as an "integral element of cosmic universe as manifestation of the orderliness of the universe, highest level harmony" [24], while the main task of the art was "... saving mankind (and personal salvation) with the help of beauty regarded as the Truth, and always from the capital letter" [25]. Deeply connected with French traditions, Poulenc was, perhaps, trying to quench this unquenchable "immortal thirst for beauty" (Ch. Baudelaire) through many beautiful melodies, which was revolutionary for the XX century. Digging through generic, social and psychological layers of Poulenc's operas, we reach the Eternal Feminine as the key code, the unreachable and transcendent Ideal in each female character. "Eternal Feminine is, first of all, Beauty - source and goal of all sublime beauty experiences in the world of art and outside it. Art is guided by the Eternal Feminine, while depictions of

It is obvious that there is a real woman behind feminocentrism of Poulenc's operas - Denise Duval. The connection between the composer and the singer was really mystical - Poulenc "discovered" her and brought her to the big stage, and she left it two years after his death at the peak of her career. It was Denise Duval to whom the composer addressed his last message several days before his death, and the words in this message were "I thank you for my last joy" [22]. 
love and female characters are defining for the author" [26].

Eternal Feminine added to the European cultural thesaurus by Goethe is philosophical perception of the medieval adoration of the Fair Lady and adoration of Virgin Mary, especially the Black Madonna.

\section{CONCLUSION}

In general, $\mathrm{XX}$ century art is characterized by disappearance of the word "feelings" from the emotional sphere and by the fact that "even "emotion" is doubted and mainly the temper is left. Emotionalistic concept of the music is ruined" [27]. Through the use of musical expression means of the XX century, Poulenc's music demonstrates atypical for its time fullness of human emotions and divine revelations: it is startingly heartfelt, with a touch of soft irony and adorned with sudden changes of moods and conditions.

Lyricism is the alpha and omega of Poulenc's music. It infuses all its layers: from lyricism in the main plot intrigues in libretti, through the sensitivity to the word in his vocal music to lyricism domination in the emotional sphere of musical content. According to E. Tsodokov, Poulenc's lyricism flows from the very essence and depth of his soul (unlike, for instance "decorative lyricism" of R. Strauss) [28]. Poulenc's humanity, softness, compassion and deep empathy are fully reflected in his music, particularly in the operas. He did not remain a chronicler in the Dialogues of the Carmelites, witness of mischief in The Breasts of the Tiresias or lady's despair in the Human Voice. He was totally involved in the destiny of his characters and felt such empathy for them that, for instance, creation of the Dialogues damaged his mental health, and the composer had to take a break from work and undergo a course of treatment for severe depression. Here, it would be appropriate to recall the brilliant definition of troubadour personality type by E. Pound - true aristocrat of emotions with infinitely sensitive character [30].

Features that, according to his contemporaries, made Poulenc non-modern - sensuality, lyricism, religiousness, certain emotional aristocratism, supremacy of lover over convenience ${ }^{6}$, ecstatic intimacy and bold sincerity - have become manifestation of, maybe not comprehended, but boldly demonstrated esthetic dominating idea of the Late Middle Ages. It is interesting that 10 years after Poulenc's death, a very violent literary discourse of neomedievalists started, and its main concern was the

Despite wide scope of genres Poulenc exercised in, the dominant ones were those connected with the word - melodies, choral pieces and operas. Poulenc repeatedly emphasized that setting words to music should be an "act of love rather than a marriage of convenience" [39, p.774] idea of the New Middle Ages. The main principles of the New Middle Ages - visuality, brightness of characters and themes, "piling-up", "combined compound" described, inter alia, in the works of U. Eco [31] apply to F. Poulenc's oeuvre and personality. Thus, it is possible to conclude that Poulenc was, to some extent, the harbinger of the new cultural paradigm. It is quite obvious that in Poulenc's case it wasn't conscious and systematic. It was the genius's sense of our epoch spirit.

\section{References}

[1] Pierre Boulez's words in the interview to the New York Time in 1984. Henahan D. MUSIC VIEW; Boulez Forgets To Forget [Electronic resource] // The New York Times. 15 November 1987. URL: http://www.nytimes.com/1987/11/15/arts/musicview-boulez-forgets-to-forget.html (access date: 25.06.2020).

[2] F. Poulenc. Correspondence, 1910-1963 / collected, selected, presented and remarked by M. Chimènes. Paris : Fayard, 1994 $1128 \mathrm{p}$.

[3] More details on isomorphic nature of artistic worlds, see Orlov G. Music Tree, 2nd edition, revised, Composer, 2005. 440 p

[4] N. Rorem, LIES: A Diary, 1986-1999 (Counterpoint: Washington D.C., 2000), p. 15.

[5] F. Poulenc. Correspondence, 1910-1963 / collected, selected, presented and annotated by M. Chimènes. Paris : Fayard, 1994 p. 587.

[6] N. Rorem, LIES: A Diary, 1986-1999 (Counterpoint: Washington D.C., 2000), p. 15.

[7] H. Lacombe. Francis Poulenc. Paris : Fayard, 2013. p. 821

[8] P. Bernac. Francis Poulenc and his melodies. Paris : BuchetChastel, 1978. p.143.

[9] A. Harman. Medieval and Early Renaissance Music. Man and His Music. Vol.1. Barrie and Rockliff (London, 1954) p.110.

[10] H. Lacombe. Francis Poulenc. Paris: Fayard, 2013. p. 788.

[11] T.P. Moschard. The sacred choral music of Francis Poulenc: a contextual and analytical study / Toby Patrick Moschard. Durham, 2004. - 111p. p. 233.

[12] L.C. Birnbaum. Black Madonna: Feminism, Religion and Politics in Italy (Boston: Northeastern University Press, 1993).

[13] J. Huynen: Mystery of Black Madonnas. 2nd edition. Éditions Garnier, Chartres 1994.

[14] V. Zharkova. Ten insights into Western European music history. Mysteries and desires of Homo Musicus. Vol. 1 / Valeriya Zharkova. - Kyiv : ArtHuss, 2018, Vol.1 p. 185.

[15] M. Warner, Alone of All Her Sex: The myth and the cult of the Virgin Mary Oxford University Press, 2016 480p. 324

[16] V. Zharkova. Ten insights into Western European music history. Mysteries and desires of Homo Musicus. Vol. 1 / Valeriya Zharkova. - Kyiv : ArtHuss, 2018, Vol.1 p. 225.

[17] F. Poulenc. I write music that sings to me / writings and interviews collected, presented and annotated by N. Southon. Paris : Fayard, 2011.

[18] more details on this H. Lacombe. Francis Poulenc. Paris Fayard, 2013. p. 121

[19] F. Poulenc. Correspondence, 1910-1963 / collected, selected, presented and annotated by M. Chimènes. Paris : Fayard, 1994 p. 25 . 
[20] V. Zharkova. Ten insights into Western European music history. Mysteries and desires of Homo Musicus. Vol. 1 / Valeriya Zharkova. - Kyiv : ArtHuss, 2018, Vol.1 p 233.

[21] C. Miller, J. Cocteau, G. Apollinaire, P. Claudel and the Group of Six : poetic-musical encounters on melodies and songs. Sprimont : Mardaga, 2003. p. 42.

[22] F. Poulenc. Correspondence, 1910-1963 / collected, selected, presented and annotated by M. Chimènes. Paris : Fayard, 1994. p. 1008.

[23] H. Hell. French musician Francis Poulenc. Paris : Fayard, 1978. 391 p., p. 346.

[24] V.V. Azarova. Antiquity in the French opera of 1890-1900's: synopsis of doctoral thesis: 17.00 .02 / N.A. Rimsky-Korsakov S. Petersburg Conservatory SPb, 2006, p. 5.

[25] History of World Literature. Vol. 7. M., Nauka, 1991. P. 268.

[26] Eyges I. R. Eternal Feminine [Electronic source] // Literature encyclopedia : Vocabulary of Literary Terms : in 2 volumes. / edited by N. Brodsky, A. Lavretsky, E. Lunina, V. LvovRogachevksy, M. Rozanov, V. Tcheshikhin-Vetrinsky B. Vol. 1. A-P. M. ; L. : L.D. Frenkel publishing house, 1925. P. 134 URL: http://feb-web.ru/feb/slt/abc/lt1/lt1-1337.htm (access date: 04.06.2020).

[27] V.N. Kholopova. Three sides of musical content [Electronic source] // Musical content: science and pedagogics : Materials of the I Russian Academic and Research Conference, December 4-5, 2000, Moscow / Executive compiling editor. B V.N. Kholopova. M. ; Ufa : RIC USIA, 2002. P. 55-76. URL: http://www.kholopova.ru/bibrus1.html (access date: 25.06.2020).

[28] E.S. Tsodokov. Electra by Richard Strauss. On 100th anniversary of the opera. [Electronic source] // OperaNews.ru : Internet magazine. January 25, 2009. URL:https://www.operanews.ru/elektra.html (access date: 5.07.2020).

[29] H. Rosenthal, J. Warrack. Opera guide / edited in French, with and introduction by R. Mancini et J.-J. Rouveroux. New edition, revised and updated. Paris : Fayard, 1995 p.774.

[30] E. Pound Psychology and Troubadours // The Spirit of Romance: New Directions Publishing, 2005 p. 87-100.

[31] U. Eco. Middle Ages have already begun / trans. from Italian by E. Balakhovskaya // Foreign literature. 1994. Vol.4. P. 257-268. 